\title{
Pertumbuhan dan Produksi Sorgum Manis Super-1 pada Waktu Aplikasi dan Dosis Pupuk ZA
}

\author{
Suwardi ${ }^{1}$ dan Suwarti ${ }^{2}$ \\ 1,2 Balai Penelitian Tanaman Serealia \\ ${ }^{1}$ Email : wardisereal@yahoo.co.id \\ ${ }^{2}$ Email : warti.smile@gmail.com
}

\begin{abstract}
Arrangement of proper dosage and application time of $Z A$ fertilizer is required to obtain Super-1 sweet sorghum optimum yield in the form of grain or stem juice. This study purpose was to establish application time and optimum dose of ZA fertilizer for Super-1 sweet sorghum variety. The study was conducted in ICERI Experimental Field Maros, South Sulawesi in August-November 2016. The experiment was arranged on two-factors randomized block design with three replications. The first-factor was four-time $Z A$ fertilizer application, which was placed on the age of 40,50,60 and 70 DAP (days after planting). The second factor was the four doses of ZA fertilizer namely 0,50 , and $75 \mathrm{~kg} \mathrm{ha}^{-1}$. Interaction between treatments had a very significant effect on grain production per ha. The highest grain production was obtained on $50 \mathrm{~kg} \mathrm{ha}^{-1}$ fertilizer applied at 40 DAP (3.30 tons ha-1). Plant response to the independent factor of fertilizer application had a very significant effect of planting height at 35 and 105 DAP, stem diameter, number of stem nodes and biomass weight (tons $\mathrm{ha}^{-1}$ ), and significantly affected to the weight of 1000 grains. Fertilizer dosage significantly affects to grain production, panicle length and volume of juice. Pearson correlation between observations variables with seed yield per hectare showed high and very significant results in stem diameter $(r=0.74)$, as well as in the variable number of nodes $(r=0.65)$. Stem diameter has the most significant direct effect to grains production per hectare on the pathway coefficient of 0.75 .
\end{abstract}

Keywords: ZA Fertilizer, Sweet Sorghum, Super-1, Pathway Analysis, Fertilizer Application

\begin{abstract}
ABSTRAK
Sorgum manis Super-1 menghasilkan produk utama berupa biji dan batang yang diperas menjadi nira sebagai bahan baku bioethanol. Dosis pupuk dan waktu pemupukan yang akurat menghasilkan panen biji, biomas dan kadar gula brix yang optimal. Tujuan penelitian adalah untuk menentukan waktu aplikasi dan dosis pupuk ZA terhadap hasil biji (ton ha $^{-1}$ ), hasil panen batang dan karakter agronomis lainnya sebagai dasar rekomendasi pemupukan. Penelitian dilaksanakan di Kebun Percobaan Balai Penelitian Tanaman Serealia, Maros Sulawesi Selatan pada bulan Agustus-November 2016. Percobaan disusun berdasarkan Rancangan Acak Kelompok (RAK) dua faktor tiga ulangan. Faktor pertama adalah empat waktu pemberian pupuk ZA yaitu pada umur tanaman $40 \mathrm{hst}, 50 \mathrm{hst}, 60 \mathrm{hst}$ dan 70 hst. Faktor kedua adalah empat dosis pupuk ZA yaitu $0 \mathrm{~kg} \mathrm{ha}^{-1}, 50 \mathrm{~kg} \mathrm{ha}^{-1}, 75 \mathrm{~kg}$ $\mathrm{ha}^{-1}$. Hasil penelitian menunjukkan interaksi antar perlakuan berpengaruh sangat nyata terhadap produksi biji ha- ${ }^{-1}$ dengan hasil tertinggi 3.30 ton $\mathrm{ha}^{-1}$ pada perlakuan pemupukan $50 \mathrm{~kg} \mathrm{ha}^{-1} \mathrm{ZA}$ yang diaplikasikan umur 40 hst. Respon tanaman terhadap faktor mandiri perlakuan waktu aplikasi pemupukan $35 \mathrm{hst}$ dan 105 hst meningkatkan tinggi tanaman, diameter batang, jumlah ruas dan bobot biomas (ton $\mathrm{ha}^{-1}$ ), serta meningkatkan bobot 1000 biji. Dosis pupuk ZA berpengaruh nyata terhadap produksi biji per ha, panjang malai dan volume nira. Korelasi Pearson antar peubah dengan hasil biji per hektar menunjukkan hasil yang tinggi dan sangat nyata dengan diameter batang $(r=0.74)$, serta nyata dengan peubah jumlah ruas $(r=0.65)$. Diameter batang memiliki pengaruh langsung terbesar terhadap produksi biji per hektar dengan koefisien sidik lintas 0.75 .
\end{abstract}

Kata kunci: Pupuk ZA, Sorgum Manis, Super-1, Sidik Lintas, Waktu Pemupukan 
http://ojs.stiperkutim.ac.id/index.php/jpt https://doi.org/10.36084/jpt..v8i2.245
Jurnal Pertanian Terpadu 8(2): 175-188, Desember 2020 ISSN 2549-7383 (online) ISSN 2354-7251 (print)

\section{Pendahuluan}

Indonesia memiliki lahan-lahan kering yang memiliki curah hujan rendah, yang dapat digunakan untuk mengembangkan tanaman sorgum (Ariska et al., 2017). Daya adaptasi yang luas pada sorgum dan sifat ketahanan terhadap cekaman kekeringan dan genangan memungkinkan tanaman ini dikembangkan di dataran rendah maupun dataran tinggi (Agung et al., 2013; Khalil et al., 2015). Sorgum juga berproduksi tinggi di lahan marginal dan relatif tahan hama/penyakit, sehingga mudah dikembangkan (Abou-Elwafa \& Shehzad, 2018; Ameen et al., 2017). Beberapa daerah di Indonesia telah mengembangkan tanaman sorgum, tercatat ekspor sorgum pernah dilakukan meskipun dalam jumlah yang terbatas ke Singapura, Taiwan, Hongkong, Malaysia dan Jepang (Sirappa, 1996; Subagio \& Syuryawati, 2013).

Semua bagian tanaman sorgum berupa batang, daun dan biji dapat dimanfaatkan untuk pakan, pangan dan bahan industri (Subagio, 2014). Batang sorgum yang diperas menghasilkan bagase atau ampas batang untuk pakan ternak (sapi, kerbau) dan air (nira) dimanfaatkan bioethanol melalui proses fermentasi (Matsakas \& Christakopoulos, 2013). Daun sorgum langsung dimanfaatkan untuk pakan ternak baik melalui pencacahan atau tanpa pecacahan (Syuryawati et al., 2017). Biji sorgum memiliki kegunaan yang luas, baik sebagai bahan baku industri pakan maupun pangan. Industri pembuatan gula, monosodium glutamat, asam amino, beras sorgum dan tepung sorgum sebagai pensubtitusi gandum/terigu dalam pembuatan makanan menggunakan sorgum sebagai bahan bakunya. Pemanfaatan batang serta daun sorgum segar sebagai bahan pakan ternak juga telah umum dilakukan (Pabendon et al., 2012; Russo \& Fish, 2012).

Sorgum manis varietas Super-1 merupakan salah satu varietas sorgum yang memiliki banyak potensi unggul, antara lain kadar brix nira yang tinggi (hingga 14.83\%), biomass (68 ton ha-1) dan volume nira mencapai 19.445 liter per hektar serta hasil biji yang memiliki rasa yang enak (Suwarti et al., 2018). Keistimewaan lain dari tanaman sorgum manis adalah daya ratun yang tinggi, sehingga dapat dipanen hasilnya beberapa kali tanpa menanam biji (Efendi et al., 2013). Hasil ratun pertama varietas Super-1 masih menunjukkan bobot biomass $73.24 \%$ dari tanaman primer (Yakob et al., 2019). Untuk menghasilkan panen sorgum manis baik berupa batang untuk diambil nira dan biji yang optimal diperlukan rekomendasi pupuk yang tepat.

Kesuburan tanah yang rendah, ketersediaan air yang minim merupakan permasalahan dalam pengembangan tanaman sorgum di lahan sub optimal. Penggunaan lahan-lahan suboptimal untuk budidaya orgum merupakan akibat terbatasnya ketersediaan lahan yang subur serta kompetisi dengan tanaman budidaya lainnya (Irawan \& Sutrisna, 2011). Salah satu upaya peningkatan produktivitas sorgum adalah melalui Jpt. Jurnal Pertanian Terpadu, Jilid 8, Nomor 2| 176 
ISSN 2354-7251 (print)

penambahan pemberian pupuk ZA (Amonium sulfat) yang memiliki kandungan $\mathrm{N}$ cukup dan harga murah sehingga dapat mengurangi biaya produksi. Pupuk urea memiliki kandungan $\mathrm{N}$ yang tinggi, namun memiliki harga yang lebih mahal dibanding pupuk ZA. Kandungan nitrogen pada ZA adalah $21 \%$ atau hampir separuh dari kandungan $\mathrm{N}$ urea (45\%) (Suminar et al., 2017).

Tergolong sebagai tanaman C4, sorgum memiliki efisiensi tinggi terhadap penggunaan air dan unsur hara terutama nitrogen (Maw et al., 2016, 2017). Pemupukan unsur $\mathrm{N}$ pada tanaman sorgum pada umumnya menggunakan pupuk organik dan pupuk anorganik diantaranya urea dan ZA. Pupuk nitrogen dibedakan atas ammonium, nitrat dan amid ajika dibedakan berdasar senyawa dasar pembentuknya. ZA merupakan pupuk yang memiliki senyawa dasar ammonium, sedangkan urea merupakan pupuk nitrogen yang memiliki senyawa dasar amida. Sifat utama $N$ dalam pupuk anorganik adalah memiliki mobilitas yang tinggi baik dalam floem maupun dalam tanah. Untuk mengurangi kehilangan unsur $\mathrm{N}$ pada pupuk urea adalah dengan penambahan pupuk ZA yang mampu mengikat $N$ urea oleh senyawa amonium $(Z A)$, sehingga seluruh unsur nitrogen diserap secara optimal oleh akar tanaman. Aplikasi pupuk ZA pada beberapa tanaman budidaya lain juga terbukti meningkatkan bobot kering tanaman dibandingkan pupuk urea (Sumbayak et al., 2018). Tujuan dari penelitian ini adalah untuk mengetahui waktu aplikasi dan dosis pupuk ZA terhadap pertumbuhan, hasil, nira dan kadar gula brix tanaman sorgum manis varietas Super-1 sebagai dasar penentuan rekomendasi pemupukan.

\section{Metode Penelitian}

Penelitian dilaksanakan di KP Maros Balai Penelitian Tanaman Serealia, Kab. Maros, Sulawesi Selatan yang dilaksanakan sepanjang bulan Agustus - November 2016 dengan ketinggian tempat $5 \mathrm{~m}$ dpl. Percobaan disusun berdasarkan Rancangan Acak Kelompok (RAK) tiga ulangan dengan dua faktor. Faktor pertama yaitu waktu aplikasi pupuk ZA yaitu aplikasi pada umur tanaman 40 hst, umur 50 hst, dan umur 75 hst. Faktor ke dua adalah dosis pupuk tunggal ZA yaitu $0 \mathrm{~kg} \mathrm{ha}^{-1}, 50 \mathrm{~kg} \mathrm{ha}^{-1}$, dan $75 \mathrm{~kg} \mathrm{ha}^{-1}$. Dosis pupuk dasar yang diberikan adalah Phonska $250 \mathrm{~kg} \mathrm{ha}^{-1}$ tanaman $7 \mathrm{hst}$ dan Urea $250 \mathrm{~kg}$ ha $^{-1}$ tanaman 30 hst. Varietas sorgum manis Super-1 ditanam pada jarak $75 \times 25 \mathrm{~cm}$ (3 biji per lubang). Ukuran plot percobaan $5 \mathrm{~m} \times 4 \mathrm{~m}$ dengan 3 ulangan dan jumlah 27 plot jarak antar plot 1 meter. Tanaman sorgum diperjarang pada umur 14 hst dan mempertahankan 2 tanaman/lubang tanam.

Peubah pengamatan penelitian ini meliputi tinggi tanaman $(\mathrm{cm})$ pada 35 hst dan $105 \mathrm{hst}$, kadar gula brix (\%), volume nira $\left(\mathrm{ml} \mathrm{kg}^{-1}\right)$ tiap $1 \mathrm{~kg}$ batang, jumlah ruas, diameter 
batang (cm), klorofil daun (unit), hasil biji (ton ha-1) dan komponen hasil (bobot 1000 biji $(\mathrm{g})$, panjang malai $(\mathrm{cm})$, dan bobot biomas (ton ha ${ }^{-1}$ ). Data yang diperoleh dianalisis menggunakan ANOVA dan di uji lanjut menggunakan Duncan pada taraf kepercayaan 5\%. Uji korelasi Pearson digunakan untuk mengetahui hubungan antar peubah pengamatan. Lebih lanjut uji sidik lintas dilakukan untuk mengetahui pengaruh langsung dan tidak langsung peubah pengamatan terhadap produksi biji sorgum manis varietas Super-1.

\section{Hasil dan Pembahasan}

\section{Tekstur dan Kimia Tanah di Lahan Percobaan Kombinasi Dosis dan Waktu Pemupukan ZA Terhadap Sorgum Manis Super-1}

Kondisi tanah di lahan percobaan menunjukkan $\mathrm{pH}$ netral (6.21), dengan tekstur clay loam atau lempung liat (Tabel 1). Tingkat kemasaman tanah yang tinggi tidak berpengaruh langsung terhadap ketersediaan $\mathrm{N}$ tanah, namun akan menghambat aktivitas microbial seperti mineralisasi $\mathrm{N}$ dari bahan organik maupun nitrifikasi (Li et al., 2018). Kadar $C$ tanah yang sedang dengan nilai $C / N$ yang tinggi serta kandungan nitrogen dalam tanah yang rendah mengindikasikan perlunya penambahan unsur nitrogen melalui pemupukan.

Tabel 1. Hasil analisis tanah sebelum penelitian, di Kebun Percobaan Balitsereal 2016, Maros

\begin{tabular}{|c|c|c|}
\hline Jenis Penetapan & Nilai Penetapan & Harkat \\
\hline Tekstur & & Lempung liat \\
\hline Liat (\%) & 31 & \\
\hline Debu (\%) & 42 & \\
\hline Pasir (\%) & 27 & \\
\hline pH : Air & 6,21 & Netral \\
\hline $\mathrm{KCl}$ & 5,57 & Sedang \\
\hline $\mathrm{N}$-total (\%) & 0,16 & Rendah \\
\hline C (\%) & 2,35 & Sedang \\
\hline $\mathrm{C} / \mathrm{N}$ & 19 & Tinggi \\
\hline $\mathrm{P}_{2} \mathrm{O}_{5} \mathrm{mg} / 100 \mathrm{~g}$ & 45 & Tinggi \\
\hline $\mathrm{P}_{2} \mathrm{O}_{5}$ Bry-l (ppm) & 131 & Sangat tinggi \\
\hline $\mathrm{K}_{2} \mathrm{O}$ & 46 & Tinggi \\
\hline $\mathrm{K}$ & 0,13 & Rendah \\
\hline $\mathrm{Ca}$ & 18,88 & Tinggi \\
\hline $\mathrm{Mg}$ & 1,87 & Sedang \\
\hline $\mathrm{Na}$ & 0,55 & Sedang \\
\hline $\mathrm{KTK}(\mathrm{me} / 100 \mathrm{~g})$ & 11,19 & Rendah \\
\hline Kejenuhan Basa (\%) & $100^{+}$ & Sangat tinggi \\
\hline
\end{tabular}

Nilai KTK memiliki kategori rendah artinya koloid tanah tidak menahan unsur hara dengan baik sehingga menjadi mudah untuk tercuci dan menjadi tidak tersedia untuk tanaman (Bachtiar \& Ura', 2017). Kejenuhan basa sering dikaitkan dengan tingkat kesuburan tanah. Kejenuhan basa pada lahan percobaan menunjukkan nilai yang sangat tinggi (100\%), merupakan indikasi dari jumlah ion $\mathrm{OH}^{-}$yang tinggi dalam larutan tanah Jpt. Jurnal Pertanian Terpadu, Jilid 8, Nomor 2| 178 
(Arifin et al., 2017). Nilai kejenuhan basa tanah dapat ditingkatkan dengan pemberian dolomit (Sihombing et al., 2019).

Curah hujan pada lokasi penelitian berdasarkan data BMKG disajikan pada Gambar 2. Curah hujan tertinggi dengan jumlah hari yang lebih banyak terjadi pada saat perlakuan pemupukan ZA 60 hst.

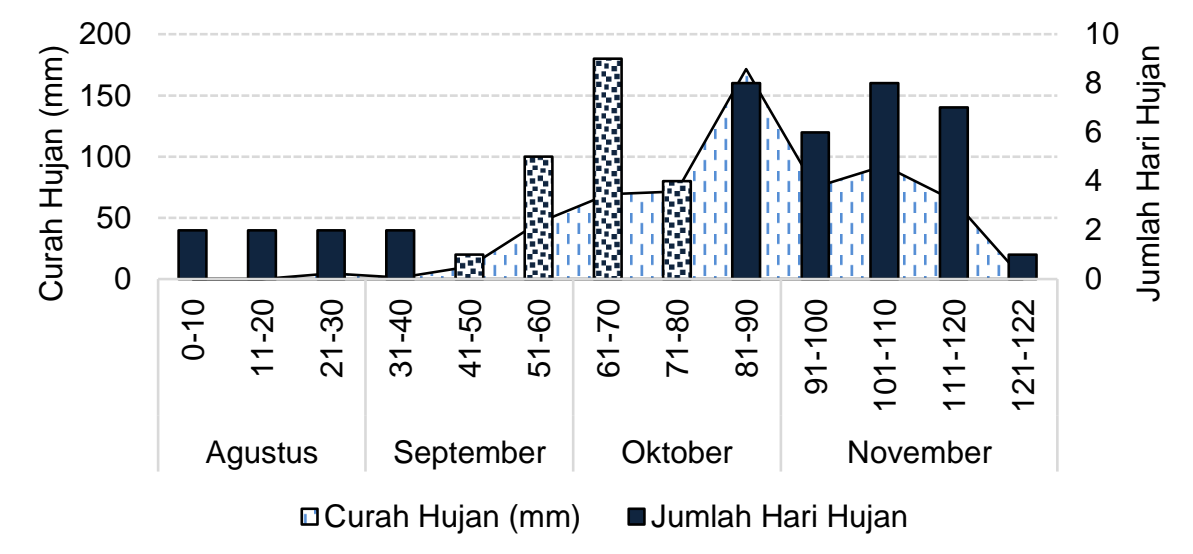

Keterangan : Pattern chart pada grafik jumlah hari hujan menunjukkan perlakuan waktu pemupukan ZA

Gambar 1. Jumlah Hari Hujan dan Curah Hujan Pada Saat Penelitian di Kebun Percobaan Balitsereal 2016

\section{Respon Tanaman Sorgum Manis Super-1 Terhadap Dosis dan Waktu Pemupukan} ZA

Hasil sidik ragam perlakuan terhadap peubah pengamatan ditunjukkan pada Tabel 2. Nilai koefisien keragaman pada percobaan ini tergolong rendah pada seluruh peubah yang diamati dengan kisaran tertinggi pada kadar gula brix (19.35\%) dan terendah pada panjang malai (3.89\%). Kriteria koefisien keragaman adalah rendah 0-25\%, sedang 25 50\%, cukup tinggi 50-75\% dan tinggi 75-100\% (Sari \& Respatijarti, 2014; Stępniak, 2011). Nilai keragaman yang rendah menunjukkan semakin tingkat tinggi akurasi peubah yang diamati pada varietas sorgum dengan waktu aplikasi dan dosis pupuk ZA. Koefisien keragaman menunjukkan keragaman terhadap peubah yang terjadi di lapangan.

Interaksi antara waktu aplikasi dan dosis pupuk ZA berpengaruh sangat nyata terhadap produksi biji sorgum manis Super-1, sedangkan pada peubah yang lain tidak menunjukkan interaksi yang nyata (Tabel 1). Unsur hara $\mathrm{N}$ pada ZA menyusun klorofil daun yang berperan menghasilkan fotosintat untuk ditraskolasikan ke biji, sehingga ketersediaannya berpengaruh terhadap produksi, waktu pemberian pupuk yang tepat meningkatkan efektifitas pemupukan. Produksi sorgum dipengaruhi oleh faktor genetik dan lingkungan. Ukuran biji sorgum yang merupakan bawaan faktor genetik mempengaruhi bobot biji (Marlina et al., 2015). 
Pengaruh mandiri waktu aplikasi pupuk ZA berpengaruh sangat nyata terhadap tinggi tanaman 35 dan 105 hst (hari setelah tanam), diameter batang, jumlah ruas dan bobot biomas serta berpengaruh nyata terhadap bobot 1000 biji. Waktu aplikasi berkaitan dengan ketersediaan unsur hara $\mathrm{N}$ sesuai dengan fase pertumbuhannya. Pembentukan sel baru pada jaringan meristem berasal dari hasil asimilasi/fotosintat yang ditranskolasikan sehingga menghasilkan sel-sel baru di ujung batang dan memicu terjadinya pembelahan, perpanjangan dan pembesaran sel untuk membentuk dinding sel dan protoplasma sehingga terjadi peningkatan tinggi tanaman dan diameter batang (Suminar et al., 2017).

Tabel 2. Hasil analisis sidik ragam varietas dengan berbagai dosis pemupukan ZA terhadap peubah yang diamati

\begin{tabular}{|c|c|c|c|c|}
\hline Peubah yang Diamati & $\begin{array}{c}\text { Waktu } \\
\text { Aplikasi }\end{array}$ & $\begin{array}{l}\text { Dosis } \\
\text { Pupuk }\end{array}$ & Interaksi & $\begin{array}{c}\text { Koefisien } \\
\text { Keragaman (\%) }\end{array}$ \\
\hline Produksi (ton ha-1) & tn & * & ** & 9.94 \\
\hline Bobot 1000 bij (g) & * & tn & tn & 5.59 \\
\hline Panjang malai $(\mathrm{cm})$ & tn & * & tn & 3.89 \\
\hline Tinggi tanaman 35 hst $(\mathrm{cm})$ & ** & tn & tn & 10.73 \\
\hline Tinggi tanaman 105 hst (cm) & ** & tn & tn & 5.27 \\
\hline Diameter batang $(\mathrm{cm})$ & ** & tn & tn & 5.93 \\
\hline Jumlah ruas & ** & tn & tn & 6.14 \\
\hline Klorofil daun 35 hst (unit) & tn & tn & tn & 5.12 \\
\hline Volume nira 1 kg batang (ml) & $\operatorname{tn}$ & * & tn & 7.37 \\
\hline Kadar gula brix (\%) & tn & tn & tn & 19.35 \\
\hline Biomas (ton ha-1) & ** & tn & tn & 16.24 \\
\hline
\end{tabular}

Keterangan : ${ }^{* *}=$ berbeda sangat nyata,${ }^{*}=$ berbeda nyata, $\mathrm{tn}=$ berbeda tidak nyata berdasarkan uji sidik ragam pada taraf kepercayaan $95 \%$.

Pengaruh mandiri dosis pupuk ZA menunjukkan hasil nyata terhadap produksi, panjang malai dan volume nira. Kandungan nitrogen pada pupuk ZA mempengaruhii pembentukan biji dan batang sorgum manis varietas Super-1. Penambahan unsur N pada tanah melalui pemupukan dapat meningkatkan pertumbuhan daun dan intensitas cahaya matahari di daun sehingga laju fotosintesis dan hasil partisi fotosintat ke biji meningkat (Napitupulu \& Winarto, 2010). Pemupukan ZA efektif meningkatkan produktivitas biji pada tanaman jagung, karena memiliki kandungan sulfur dalam bentuk sulfat $\left(\mathrm{SO}_{4}{ }^{2-}\right)$ yang dapat segera diserap tanaman dan berperan dalam proses pembentukan biji (Aisyah et al., 2015).

\section{Produksi Biji Sorgum Manis Super-1 pada Interaksi antara Dosis dan Waktu Pemupukan ZA}

Produksi biji per hektar tertinggi diperoleh pada interaksi perlakuan dosis pupuk ZA $50 \mathrm{~kg} \mathrm{ha}^{-1}$ yang diaplikasikan pada umur tanaman 40 hst (Gambar 1) dengan hasil 3.30 ton ha ${ }^{-1}$. Pemupukan ZA pada umur tanaman 60 hst dan 70 hst menunjukkan hasil yang relatif lebih rendah dibandingkan pemupukan ZA pada umur tanaman 40 dan 50 hst. Hasil panen biji sorgum manis Super-1 paling rendah diperoleh pada pemupukan ZA Jpt. Jurnal Pertanian Terpadu, Jilid 8, Nomor 2 | 180 
dengan dosis $50 \mathrm{~kg} \mathrm{ha}^{-1}$ yang diaplikasikan pada umur tanaman $60 \mathrm{hst}$, berbeda tidak nyata dibandingkan dengan pemupukan ZA pada seluruh kombinasi perlakuan selain dosis $50 \mathrm{~kg} \mathrm{ha}^{-1}$ pada 40 hst. Pemupukan unsur $\mathrm{N}$ pada tanaman sorgum yang dilakukan pada umur tanaman yang terlalu tua, tidak efektif untuk meningkatkan hasil. Pemupukan nitrogen lebih efektif untuk meningkatkan pertumbuhan vegetative tanaman. Sifat nitrogen yang higroskopis menyebabkan nitrogen harus segera dimanfaatkan tanaman sebelum tercuci dalam larutan tanah (Sumbayak et al., 2018)

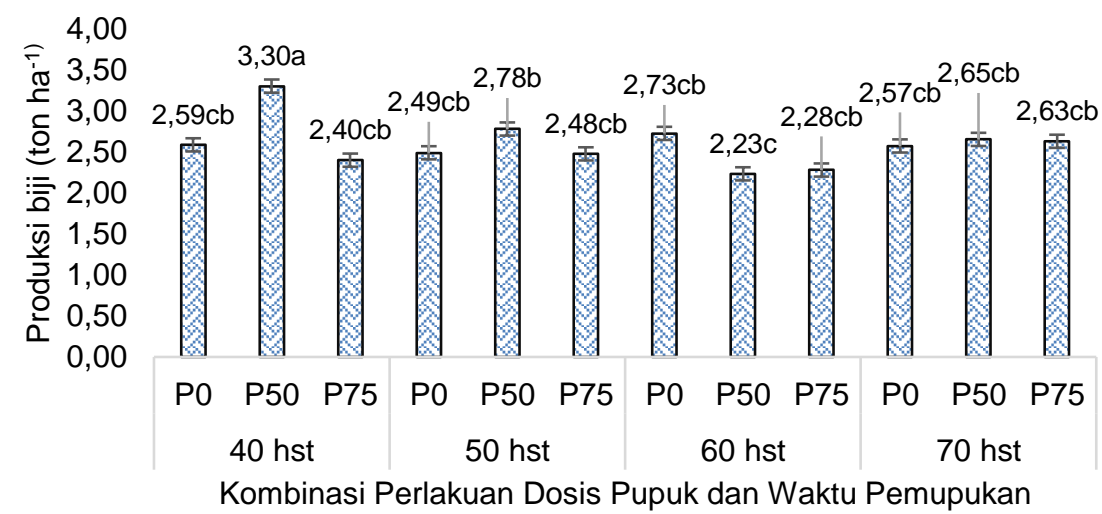

Keterangan : Angka-angka yang diikuti oleh huruf yang sama menunjukkan tidak berbeda nyata berdasarkan uji Duncan 5\%.

Gambar 2. Produksi Biji Sorgum Manis Super-1 pada Perlakuan Kombinasi Dosis Pupuk dan Waktu Pemupukan ZA

Tabel 3. Pengaruh waktu aplikasi dan dosis pupuk ZA terhadap rata-rata produksi biji sorgum manis Super-1.

\begin{tabular}{cccc}
\hline Waktu Aplikasi & \multicolumn{3}{c}{ Dosis Pupuk ZA } \\
\cline { 2 - 4 } (hst) & $\mathbf{P 0}\left(\mathbf{0} \mathbf{~ k g ~ h a}^{-1}\right)$ & $\mathbf{P 5 0}\left(\mathbf{5 0} \mathbf{~ k g ~ h a}^{-1}\right)$ & $\mathbf{P 7 5}\left(\mathbf{7 5} \mathbf{~ k g ~ h a}^{-1}\right)$ \\
\hline $40 \mathrm{hst}$ & $2.59 \mathrm{aB}$ & $\mathbf{3 . 3 0} \mathbf{~ a A}$ & $2.40 \mathrm{aB}$ \\
$50 \mathrm{hst}$ & $2.49 \mathrm{aA}$ & $2.78 \mathrm{bA}$ & $2.48 \mathrm{aA}$ \\
$60 \mathrm{hst}$ & $2.73 \mathrm{aA}$ & $2.23 \mathrm{cB}$ & $2.28 \mathrm{aB}$ \\
$70 \mathrm{hst}$ & $2.57 \mathrm{aA}$ & $2.65 \mathrm{bcA}$ & $2.63 \mathrm{aA}$ \\
\hline
\end{tabular}

Keterangan : Angka-angka yang diikuti oleh huruf kecil yang sama pada kolom yang sama (dosis pupuk ZA), dan angka yang diikuti huruf kapital yang sama pada baris yang sama (waktu aplikasi pupuk) menunjukkan tidak berbeda nyata berdasarkan uji Duncan $5 \%$.

Pemupukan ZA dengan dosis $0 \mathrm{~kg} \mathrm{ha}^{-1}$ menunjukkan hasil biji sorgum per hektar yang tidak berbeda nyata pada semua perlakuan waktu aplikasi pupuk, demikian juga pemupukan dosis ZA $75 \mathrm{~kg} \mathrm{ha}^{-1}$. Berdasarkan waktu aplikasi pupuk ZA pada Tabel 3, aplikasi ZA saat umur tanaman 40 hst menunjukkan hasil produksi biji sorgum yang tertinggi berbeda tidak nyata dengan perlakuan pada umur 50 hst dan 70 hst. Sedangkan pemupukan umur tanaman 60 hst menunjukkan hasil biji paling rendah meskipun berbeda tidak nyata dibandingkan pemupukan umur tanaman 50 dan 70 hst. Pemberian dosis pupuk nitrogen di lahan kering hanya akan meningkatkan hasil tanaman sampai batas tertentu. Pemupukan $\mathrm{N}$ lebih efektif untuk meningkatkan hasil tanaman jika diberikan pada lahan yang memiliki kecukupan air (Moser et al., 2006). Data curah hujan pada 
Gambar 1 menunjukkan pada saat pemupukan ZA perlakuan $40 \mathrm{hst}$, curah hujan rendah, namun pada minggu berikutnya diikuti curah hujan yang lebih tinggi sehingga melarutkan pupuk yang diberikan. Pemupukan N pada minggu berikutnya tidak terlalu efektif untuk meningkatkan produktivitas biji, karena tanaman sorgum telah mulai memasuki fase generatif.

\section{Respon Agronomis Sorgum Manis Super-1 Terhadap Pengaruh Mandiri Dosis dan Waktu Pemupukan ZA}

Respon tanaman terhadap pemupukan dan waktu pemupukan ZA berdasarkan pengaruh mandiri ditampilkan pada Tabel 4 dan Tabel 5. Bobot 1000 biji tertinggi diperoleh pada perlakuan waktu aplikasi pupuk $40 \mathrm{hst}(29.48 \mathrm{~g})$. Bobot biomass tertinggi diperoleh pada pemupukan 70 hst (46.87 ton ha-1) tidak berbeda nyata dengan perlakuan 40 hst (46.56 ton ha-1 ${ }^{-1}$. Panjang malai terpanjang diperoleh pada dosis pupuk ZA 0 dan 50 $\mathrm{kg} \mathrm{ha}^{-1}$ dengan panjang masing-masing $30.12 \mathrm{~cm}$ dan $30.37 \mathrm{~cm}$. Dosis $75 \mathrm{~kg} \mathrm{ha}^{-1}$ menurunkan panjang malai, yang menunjukkan pemberian dosis $\mathrm{N}$ tinggi menurunkan komponen hasil. Volume nira yang lebih tinggi diperoleh pada perlakuan tanpa pupuk ZA sebesar $375.83 \mathrm{ml} \mathrm{kg}^{-1}$.

Tabel 4. Rata-rata pengaruh mandiri waktu aplikasi dan dosis pupuk ZA terhadap produksi, bobot biji, panjang malai, tinggi tanaman dan klorofil daun

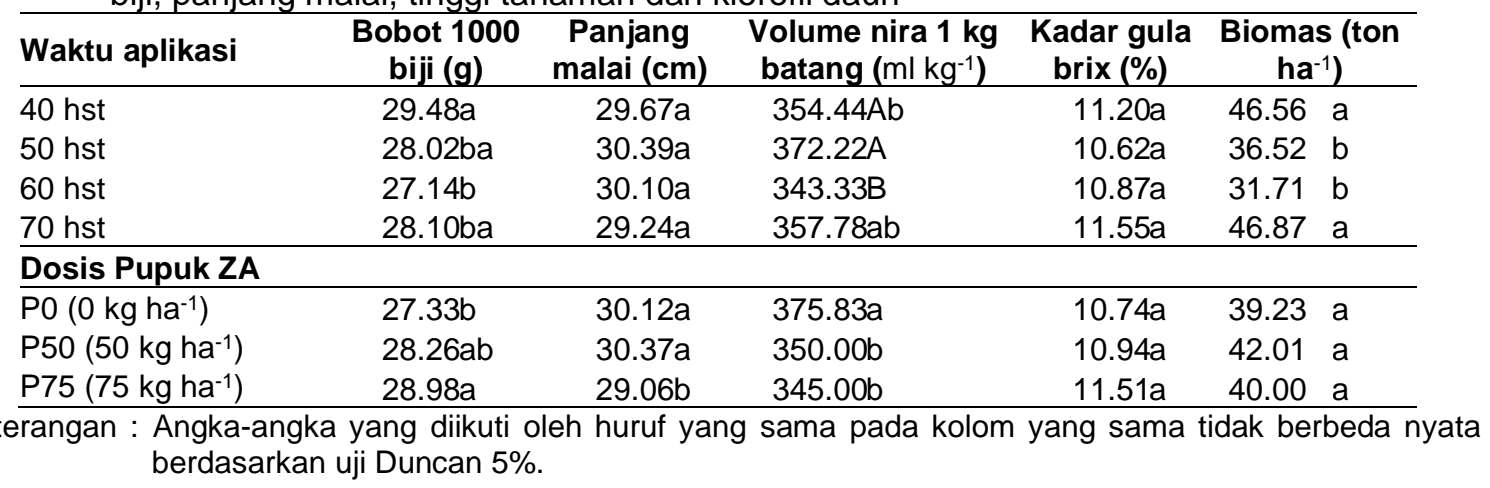

Tinggi tanaman sorgum manis Super-1 umur 35 hst dan 105 hst pada perlakuan pemupukan ZA 40 hst $(81.37 \mathrm{~cm}-285.28 \mathrm{~cm})$ serta 70 hst $(80.04 \mathrm{~cm}-283.83 \mathrm{~cm})$ menunjukkan nilai lebih tinggi dibandingkan perlakuan waktu pemupukkan lainnya. Hasil ini juga terlihat seiring dengan ukuran diameter batang yang lebih besar pada perlakuan pemupukan $40 \mathrm{hst}$ dan $70 \mathrm{hst}$ sebesar $2.17 \mathrm{~cm}$ dan $2.13 \mathrm{~cm}$. Pada peubah jumlah ruas, pemupukan 40 hst menunjukkan hasil yang lebih tinggi dibandingkan perlakuan lain dengan jumlah ruas rata-rata 10.89 buah. Perlakuan pupuk ZA pada umur tanaman 40 hst menunjukkan nilai yang baik pada lebih banyak karakter generatif maupun karakter vegetatif dibandingkan perlakuan waktu pemupukan 50 hst, 60 hst dan 70 hst. Penambahan pupuk ZA pada umur tanaman 40 hst diperlukan jika ingin meningkatkan 
ISSN 2354-7251 (print)

bobot 1000 biji, tinggi tanaman, diameter batang dan jumlah ruas. Dosis $50 \mathrm{~kg} \mathrm{ha}^{-1} \mathrm{ZA}$ hanya meningkatkan panjang malai.

Tabel 5. Rata-rata pengaruh mandiri waktu aplikasi dan dosis pupuk ZA terhadap tinggi tanaman, diameter batang, jumah ruas, dan klorofil daun

\begin{tabular}{lccccc}
\hline Waktu aplikasi (hst) & $\begin{array}{c}\text { Tinggi } \\
\text { tanaman } 35 \\
\text { hst } \mathbf{( c m})\end{array}$ & $\begin{array}{c}\text { Tinggi } \\
\text { tanaman 105 } \\
\text { hst (cm) }\end{array}$ & $\begin{array}{c}\text { Diameter } \\
\text { batang (cm) }\end{array}$ & Jumlah ruas Klorofil daun \\
35 hst (unit)
\end{tabular}

Keterangan : Angka-angka yang diikuti oleh huruf yang sama pada kolom yang sama tidak berbeda nyata berdasarkan uji Duncan 5\%.

\section{Korelasi dan Sidik Lintas Perlakuan Terhadap Hasil Biji}

Tabel 6 dan Gambar 3 menampilkan hasil uji korelasi semua peubah pengamatan dengan produksi biji. Nilai korelasi mendefinisikan hubungan antar karakter pengamatan dengan karakter utama berupa hasil (Aryana, 2009). Korelasi antar peubah pengamatan dengan produksi biji menunjukkan diameter batang dan jumlah ruas memiliki korelasi tinggi yang sangat nyata dan nyata terhadap produksi biji sorgum manis Super-1 dengan nilai koefisien masing-masing $r=0.74$ dan $r=0.65$. Peubah tinggi tanaman 105 hst dan biomassa tanaman per hektar juga menunjukkan nilai yang tinggi (0.54 dan 0.52), meskipun tidak nyata berdasarkan uji Pearson.

Tabel 6. Korelasi Pearson antar peubah perlakuan dan antara perlakuan terhadap hasil biji sorgum manis Super-1 per hektar

\begin{tabular}{|c|c|c|c|c|c|c|c|c|c|c|}
\hline & $\mathbf{Y}$ & $\mathrm{X} 1$ & $\mathrm{X} 2$ & $\mathrm{X} 3$ & $\mathrm{X} 4$ & $\times 5$ & $\mathrm{X} 6$ & $\mathrm{X} 7$ & $\mathrm{X} 8$ & $\mathrm{X} 9$ \\
\hline$\overline{X 1}$ & $0.42 \mathrm{tn}$ & & & & & & & & & \\
\hline X2 & 0.37 tn & -0.34 tn & & & & & & & & \\
\hline X3 & 0.42 tn & $0.59^{*}$ & -0.43 tn & & & & & & & \\
\hline X4 & 0.07 tn & $-0.14 \mathrm{tn}$ & -0.43 tn & $0.31 \mathrm{tn}$ & & & & & & \\
\hline X5 & $0.54 \mathrm{tn}$ & $0.52 \mathrm{tn}$ & $-0.40 \mathrm{tn}$ & $0.74^{\star \star}$ & $0.38 \mathrm{tn}$ & & & & & \\
\hline X6 & $0.74^{\star \star}$ & $0.51 \mathrm{tn}$ & -0.19 tn & $0.74^{\star \star}$ & $0.53 \mathrm{tn}$ & $0.82^{* *}$ & & & & \\
\hline X7 & $0.65^{\star}$ & $0.61^{*}$ & -0.05 tn & $0.73^{\star *}$ & $0.29 \mathrm{tn}$ & $0.71^{*}$ & $0.85^{\star \star}$ & & & \\
\hline X8 & $0.52 \mathrm{tn}$ & $0.52 \mathrm{tn}$ & $-0.34 \mathrm{tn}$ & $0.82^{\star \star}$ & $0.37 \mathrm{tn}$ & $0.84^{\star \star}$ & $0.81^{\star *}$ & $0.86^{\star \star}$ & & \\
\hline X9 & $-0.06 \mathrm{tn}$ & $-0.46 \mathrm{tn}$ & $0.30 \mathrm{tn}$ & $-0.06 \mathrm{tn}$ & $-0.02 \operatorname{tn}$ & 0.15 tn & 0.00 tn & $-0.07 \mathrm{tn}$ & $-0.04 \mathrm{tn}$ & \\
\hline $\mathbf{X 1 0}$ & $-0.37 \mathrm{tn}$ & $0.35 \mathrm{tn}$ & $-0.61^{*}$ & 0.40 tn & $0.05 \mathrm{tn}$ & $0.18 \mathrm{tn}$ & $0.05 \mathrm{tn}$ & 0.30 tn & 0.40 tn & $-0.33 \operatorname{tn}$ \\
\hline & $\begin{array}{l}\text { tn=tidak } \\
Y=\text { produ } \\
\text { hst (cm) } \\
(\mathrm{cm}) ; \mathrm{X} \\
\mathrm{X} 10=\mathrm{Kan}\end{array}$ & gula b & $\begin{array}{l}\text { daun } \\
\text { uas; } X \\
(\%)\end{array}$ & $\begin{array}{l}\text { hst } \\
\text { Bio }\end{array}$ & "xt & $"=$ berbo & da & nyata be & $\begin{array}{l}\text { rdasark } \\
3=\text { Tingg } \\
\text {; } 6=\text { Dia } \\
\mathrm{kg} \text { bata }\end{array}$ & $\begin{array}{l}\text { nete } \\
g \quad(\end{array}$ \\
\hline
\end{tabular}

Warna biru yang lebih pekat pada Gambar 3 menunjukkan tingkat korelasi antar peubah amatan yang lebih kuat. Peubah yang berkorelasi nyata dengan diameter batang dan jumlah ruas berdasarkan Tabel 6 dan Gambar 3 adalah bobot biomassa per hektar, tinggi tanaman 35 hst dan 105 hst serta diameter batang. Panjang malai dan nilai Brix 
http://ojs.stiperkutim.ac.id/index.php/jpt https://doi.org/10.36084/jpt..v8i2.245
Jurnal Pertanian Terpadu 8(2): 175-188, Desember 2020

ISSN 2549-7383 (online)

ISSN 2354-7251 (print)

menunjukkan korelasi tinggi dan pengaruh yang saling melemahkan. Nilai korelasi positif dan memiliki koefisien lebih dari 0.5 mengindikasikan korelasi yang kuat antar peubah pengamatan (Wardana et al., 2015).

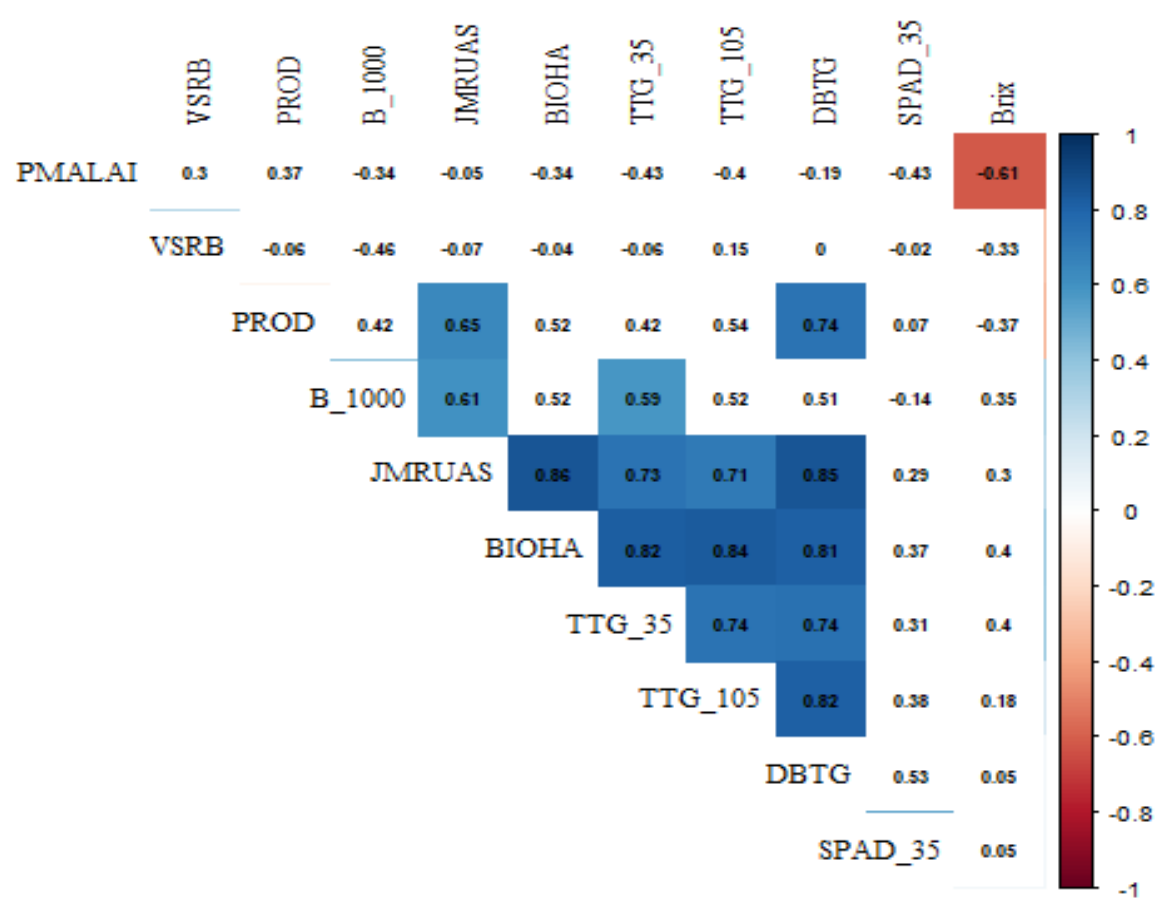

Keterangan: Warna biru yang lebih pekat menunjukkan korelasi pearson yang semakin nyata, semakin merah menjukkan korelasi yang semakin tidak nyata

Gambar 3. Korelasi Antar Karakter Pada Kombinasi Waktu Aplikasi dan Dosis Pupuk ZA Sorgum Manis Super-1.

Analisis sidik lintas memisahkan pengaruh langsung dan tidak langsung peubah pengamatan terhadap komponen utama berdasarkan nilai korelasi (Saputra et al., 2017). Pengaruh langsung tertinggi diperoleh pada panjang malai, tinggi tanaman umur $105 \mathrm{hst}$ dan diameter batang. Jumlah ruas batang sorgum memberikan pengaruh langsung yang negatif terhadap produksi biji sorgum, peningkatan jumlah ruas batang akan menurunkan produksi. Nilai residu pengaruh langsung dan tidak langsung adalah $\mathrm{R}=0.06$ yang memiliki makna keseluruhan karakter amatan menjelaskan sebagian besar pengaruh langsung (direct) dan tidak langsung (indirect) terhadap hasil (Rohaeni \& Permadi, 2012). 
Tabel 7. Matriks sidik lintas karakter agronomis terhadap produksi biji sorgum

\begin{tabular}{|c|c|c|c|c|c|c|c|c|c|c|c|c|}
\hline \multirow{2}{*}{ Karakter } & \multirow{2}{*}{$\begin{array}{l}\text { Pengaruh } \\
\text { Langsung }\end{array}$} & \multicolumn{10}{|c|}{ Pengaruh tidak langsung } & \multirow{2}{*}{$\begin{array}{c}\text { Pengaruh } \\
\text { Total }\end{array}$} \\
\hline & & $\mathbf{X} 1$ & $\mathrm{X} 2$ & X3 & $\mathbf{X 4}$ & $\mathrm{X} 5$ & $\mathrm{X6}$ & $\mathrm{X} 7$ & $\mathrm{X8}$ & $\mathrm{X9}$ & $\mathrm{X} 10$ & \\
\hline $\mathrm{X} 1$ & 0.25 & & -0.36 & 0.07 & -0.01 & 0.26 & 0.38 & -0.51 & 0.15 & 0.17 & 0.01 & 0.42 \\
\hline X2 & 1.05 & -0.09 & & -0.05 & -0.02 & -0.20 & -0.14 & 0.04 & -0.10 & -0.11 & -0.01 & 0.37 \\
\hline X3 & 0.11 & 0.15 & -0.45 & & 0.02 & 0.37 & 0.56 & -0.61 & 0.24 & 0.02 & 0.01 & 0.42 \\
\hline X4 & 0.06 & -0.04 & -0.45 & 0.04 & & 0.19 & 0.40 & -0.24 & 0.11 & 0.01 & 0.00 & 0.07 \\
\hline X5 & 0.50 & 0.13 & -0.42 & 0.09 & 0.02 & & 0.62 & -0.59 & 0.25 & -0.06 & 0.00 & 0.54 \\
\hline X6 & 0.75 & 0.13 & -0.20 & 0.09 & 0.03 & 0.41 & & -0.71 & 0.24 & 0.00 & 0.00 & 0.74 \\
\hline $\mathrm{X} 7$ & -0.83 & 0.15 & -0.05 & 0.08 & 0.02 & 0.36 & 0.64 & & 0.25 & 0.03 & 0.01 & 0.65 \\
\hline X8 & 0.29 & 0.13 & -0.36 & 0.09 & 0.02 & 0.42 & 0.61 & -0.71 & & 0.01 & 0.01 & 0.52 \\
\hline X9 & -0.37 & -0.12 & 0.32 & -0.01 & 0.00 & 0.08 & 0.00 & 0.06 & -0.01 & & -0.01 & -0.06 \\
\hline $\mathrm{X} 10$ & 0.02 & 0.09 & -0.64 & 0.05 & 0.00 & 0.09 & 0.04 & -0.25 & 0.12 & 0.12 & & -0.37 \\
\hline Sisaan & 0.06 & & & & & & & & & & & \\
\hline
\end{tabular}

Faktor residu $\quad 0.00$

Keterangan : tn=tidak berbeda nyata; “*”=berbeda nyata; "**”=berbeda sangat nyata berdasarka uji Pearson; $\mathrm{Y}=$ produksi (ton ha-1); $\mathrm{X} 1=$ Bobot 1000 biji $(\mathrm{g}) ; \mathrm{X} 2=$ Panjang malai $(\mathrm{cm}) ; \mathrm{X} 3=$ Tinggi tanaman 35 hst (cm); X4=Klorofil daun 35 hst (unit); X5=Tinggi tanaman 105 hst (cm); X6=Diameter batang $(\mathrm{cm}) ; X 7=$ Jumlah ruas; $X 8=$ Biomas (ton ha $\left.{ }^{-1}\right) ; X 9=$ Volume nira $1 \mathrm{~kg}$ batang $\left(\mathrm{ml} \mathrm{kg}^{-1}\right)$; $\mathrm{X} 10=$ Kadar gula brix (\%)

Hubungan antara peubah yang memiliki pengaruh langsung dan tidak langsung diilustrasikan dalam diagram pada Gambar 3. Panjang malai, tinggi tanaman $105 \mathrm{hst}$, diameter batang dan jumlah ruas memiliki pengaruh langsung paling besar terhadap produksi biji sorgum manis varietas Super-1. Sedangkan nilai brix mempengaruhi hasil melalui panjang malai, dengan pengaruh yang negatif. Semakin tinggi niilai brix akan menurunkan panjang malai yang pada akhirya menurunkan hasil biji. Bobot biomass per hektar mempengaruhi hasil melalui diameter batang dengan pengaruh positif, namun mempengaruhi hasil melalui jumlah ruas dengan pengaruh tidak langsung yang negative. Pertumbuhan tanaman yang baik akan mendukung perolehan hasil yang baik (Wahid \& Maintang, 2017).

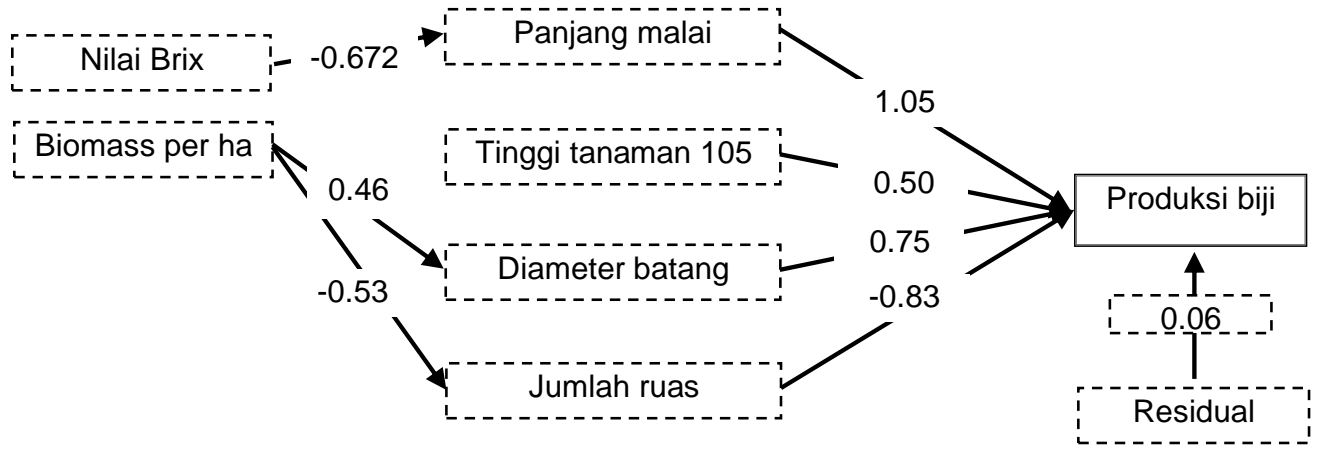

Gambar 4. Diagram Sidik Lintas Pengaruh Langsung dan Tidak Langsung Karakter Agronomis Terhadap Hasil Biji Sorgum Manis Pada Perlakuan Kombinasi Waktu Aplikasi dan Dosis Pupuk ZA. 
http://ojs.stiperkutim.ac.id/index.php/jpt https://doi.org/10.36084/jpt..v8i2.245
Jurnal Pertanian Terpadu 8(2): 175-188, Desember 2020 ISSN 2549-7383 (online) ISSN 2354-7251 (print)

\section{Kesimpulan}

Perlakuan dosis dan waktu pemupukan ZA menunjukkan interaksi nyata hanya pada peubah produktivitas. Produksi biji sorgum manis Super-1 dengan hasil tertinggi (3.30 ton ha-1) diperoleh pada kombinasi perlakuan pupuk ZA $50 \mathrm{~kg} \mathrm{ha}^{-1}$ yang diberikan saat tanaman berumur 40 hst. Penambahan pupuk ZA tidak efektif untuk meningkatkan hasil pada semua peubah jika diberikan melewati umur tanaman 40 hst. Penambahan dosis pupuk ZA maksimal yang dapat diberikan adalah $50 \mathrm{~kg} \mathrm{ha}^{-1}$. Diameter batang dan jumlah ruas berkorelasi tinggi dengan produksi biji Sorgum manis Super-1. Peubah panjang malai, tinggi tanaman $105 \mathrm{hst}$, dan diameter batang memiliki pengaruh langsung terhadap peningkatan hasil biji, sedangkan jumlah ruas berpengaruh langsung terhadap penurunan hasil biji sorgum manis Super-1.

\section{Daftar Pustaka}

Abou-Elwafa, S. F., \& Shehzad, T. (2018). Genetic identification and expression profiling of drought responsive genes in sorghum. Environmental and Experimental Botany, 155, 12-20. https://doi.org/10.1016/j.envexpbot.2018.06.019

Agung, I. G. A. M. S. gung, Sardiana, I. K., Diara, I. W., \& Nurjaya, I. G. M. O. (2013). Adaptation, biomass and ethanol yields of sweet sorghum (Sorghum bicolor (L.) Moench) varieties at dryland farming areas of jimbaran Bali, Indonesia. Journal of Biology, Agriculture and Healthcare, 3(17), 110-115. http://iiste.org/Journals/index.php/JBAH/article/view/8961

Aisyah, A., Suastika, I. W., \& Suntari, R. (2015). Pengaruh aplikasi beberapa pupuk sulfur terhadap residu, serapan, serta produksi tanaman jagung di Mollisol Jonggol, Bogor, Jawa Barat. Jurnal Tanah dan Sumberdaya Lahan, 2(1), 93-101. https://jtsl.ub.ac.id/index.php/jtsl/article/view/118/128

Ameen, A., Yang, X., Chen, F., Tang, C., Du, F., Fahad, S., \& Xie, G. H. (2017). Biomass yield and nutrient uptake of energy sorghum in response to nitrogen fertilizer rate on marginal land in a Semi-Arid region. Bioenergy Research, 10(2), 363-376. https://doi.org/10.1007/s12155-016-9804-5

Arifin, M., Yuniarti, A., \& Dahliani, D. (2017). Pengaruh abu vulkanik Gunung Sinabung dan batuan fosfat dalam bentuk nanopartikel terhadap retensi $\mathrm{P}$, delta $\mathrm{pH}$ dan kejenuhan basa pada Andisol Ciater Jawa Barat. Jur. Agroekotek, 9(1), 260-264.

Ariska, T., Sebayang, H. T., \& Suminarti, N. E. (2017). Upaya efisiensi pemanfaatan lahan melalui penanaman tanaman sela dalam sistem tanam tumpangsari dengan tanaman sorgum di lahan kering. Jurnal Produksi Tanaman, 5(8), 1367-1374.

Aryana, I. M. (2009). Korelasi fenotipik, genotipik dan sidik lintas serta implikasinya pada seleksi padi beras merah. Crop Agro, 2(1), 70-78.

Bachtiar, B., \& Ura', R. (2017). Pengaruh tegakan lamtoro gung Leucaena leucocephala L . terhadap kesuburan tanah di kawasan hutan Ko'mara Kabupaten Takalar. Jurnal Ilmu Alam dan Lingkungan, 8(15), 1-6.

Efendi, R., Aqil, M., \& Pabendon, M. (2013). Evaluasi genotipe sorgum manis ( $<\mathrm{i}>$ Sorghum bicolor $<\mathrm{i} />$ (L.) Moench) produksi biomass dan daya ratun tinggi. Penelitian Pertanian Tanaman Pangan, 32(2), 116-125. 
ISSN 2354-7251 (print)

Irawan, B., \& Sutrisna, N. (2011). Prospek pengembangan sorgum di Jawa Barat mendukung diversifikasi pangan. Forum Agro Ekonomi, 7(2), 87-105. http://pse.litbang.deptan.go.id/ind/pdffiles/FAE29-2c.pdf

Khalil, S. R. A., Abdelhafez, A. A., \& Amer, E. A. M. (2015). Evaluation of bioethanol production from juice and bagasse of some sweet sorghum varieties. Annals of Agricultural Sciences, 60(2), 317-324. https://doi.org/10.1016/j.aoas.2015.10.005

Li, Y., Chapman, S. J., Nicol, G. W., \& Yao, H. (2018). Nitrification and nitrifiers in acidic soils. Soil Biology and Biochemistry, 116(November 2017), 290-301. https://doi.org/10.1016/j.soilbio.2017.10.023

Marlina, Zuhry, E., \& Nurbaiti. (2015). Aplikasi tiga dosis pupuk fosfor pada empat varietas sorgym (Sorghum bicolor (L.) Moench) dalam meningkatkan komponen hasil dan mutu fisiologis benih. JOM Faperta, 2(2), 1-14. https://doi.org/10.3969/j.issn.10080813.2015.03.002

Matsakas, L., \& Christakopoulos, P. (2013). Fermentation of liquefacted hydrothermally pretreated sweet sorghum bagasse to ethanol at high-solids content. Bioresource Technology, 127, 202-208. https://doi.org/10.1016/j.biortech.2012.09.107

Maw, M. J. W., Houx, J. H., \& Fritschi, F. B. (2016). Sweet sorghum ethanol yield component response to nitrogen fertilization. Industrial Crops and Products, 84, 4349. https://doi.org/10.1016/j.indcrop.2016.01.038

Maw, M. J. W., Houx, J. H., \& Fritschi, F. B. (2017). Maize, sweet sorghum, and high biomass sorghum ethanol yield comparison on marginal soils in Midwest USA. Biomass and Bioenergy, 107(March), 164-171. https://doi.org/10.1016/j.biombioe.2017.09.021

Moser, S. B., Feil, B., Jampatong, S., \& Stamp, P. (2006). Effects of pre-anthesis drought, nitrogen fertilizer rate, and variety on grain yield, yield components, and harvest index of tropical maize. Agricultural Water Management, 81(1-2), 41-58. https://doi.org/10.1016/j.agwat.2005.04.005

Napitupulu, D., \& Winarto, L. (2010). Pengaruh Pemberian Pupuk N Dan K Terhadap Pertumbuhan Dan Produksi Bawang Merah. Jurnal Hortikultura, 20(1), 136783. https://doi.org/10.21082/jhort.v20n1.2010.p

Pabendon, M. B., Sarungallo, R., \& Mas'ud, S. (2012). Pemanfaatan nira batang, bagas, dan biji sorgum manis sebagai bahan baku bioetanol. Penelitian Pertanian Tanaman Pangan, 31(3), 180-187.

Rohaeni, W. R., \& Permadi, K. (2012). Analisis sidik lintas beberapa karakter komponen hasil terhadap daya hasil padi sawah pada aplikasi Agrisimba. Agrotrop, 2(2), 185190.

Russo, V. M., \& Fish, W. W. (2012). Biomass, extracted liquid yields, sugar content or seed yields of biofuel feedstocks as affected by fertilizer. Industrial Crops and Products, 36(1), 555-559. https://doi.org/10.1016/j.indcrop.2011.11.019

Saputra, T. E., Barmawi, M., Ermawati, E., \& Sa'diyah, N. (2017). Korelasi dan analisis lintas komponen komponen hasil kedelai famili F6 hasil persilangan Wilis X B3570. Jurnal Penelitian Pertanian Terapan, 16(1), 54-60. https://doi.org/10.25181/jppt.v16i1.76 
Sari, W. P., \& Respatijarti, D. (2014). Keragaman dan heritabilitas 10 genotip pada cabai besar (Capsicum annuum L .). Jurnal Produksi Tanaman, 2(4), 301-307.

Sihombing, J. E., Marbun, P., \& Marpaung, P. (2019). Pemetaan status kesuburan tanah pada lahan kopi Arabika di Kecamatan Lumban Julu Kabupaten Julu Kabupaten Toba Samosir. Jurnal Agroekoteknologi FP USU, 7(1), 239-245.

Sirappa, M. P. (1996). Prospek Pengembangan Sorgum di Indonesia sebagai Komoditas Alternatif untuk Uangan, Pakan, dan Industri. Jurnal Litbang Pertanian, 22(4), 133140.

Stępniak, C. (2011). Coefficient of Variation. In International Encyclopedia of Statistical Science (hal. 267-267). https://doi.org/10.1007/978-3-642-04898-2_177

Subagio, H. (2014). Perakitan dan Pengembangan Varietas Unggul Sorgum. Balai Penelitian Tanaman Serelia, 9(1), 39-50.

Subagio, H., \& Syuryawati. (2013). Wilayah penghasil dan ragam penggunaan sorgum di Indonesia. In Sorgum (Inovasi Teknologi dan Pengembangan) (hal. 291).

Sumbayak, E. R. M., Sunaryo, \& Widaryanto, E. (2018). Pengaruh kombinasi dosis pupuk Urea dan ZA terhadap pertumbuhan dan hasil tanaman kailan (Brassica oleraceae var . Alboglabra). Jurnal Produksi Tanaman, 6(9), 2111-2117.

Suminar, R., Suwarto, \& Purnamawati, H. (2017). Penentuan dosis optimum pemupukan N, P, dan K pada sorgum (Sorghum bicolor [L.] Moench). Jurnal IImu Pertanian Indonesia, 22(1), 6-12. https://doi.org/10.18343/jipi.22.1.6

Suwarti, Efendi, R., Massinai, R., \& Pabendon, M. B. B. (2018). Evaluation of sweet sorghum (Sorghum bicolor L.[ Moench ]) on several population density for bioethanol production. IOP Conference Series: Earth and Environmental Science, 141(012032), 1-11. https://doi.org/10.1088/1755-1315/141/1/012032

Syuryawati, Lalu, M., \& Pabendon, M. (2017). Peningkatan produksi brangkasan sorgum mendukung ketersediaan pakan dan peningkatan pendapatan petani. Prosiding Seminar Nasional Teknologi Peternakan dan Veteriner, 566-574.

Wahid, A., \& Maintang. (2017). Sidik lintas dalam penentuan karakter yang berpengaruh terhadap hasil kedelai pada lahan kering masam. Buletin Inovasi Teknologi Pertanian, 502(11), 31-36.

Wardana, C. K., Karyawati, A. S., \& Makmur, S. M. (2015). Keragaman hasil, heritabilitas dan korelasi F3 hasil persilangan kedelai (Glycine max L. Merril) varietas Anjasmoro dengan varietas Tanggamus, Grobogan, Galur AP dan UB. Jurnal Produksi Tanaman, 3(3), 182-188.

Yakob, Y., Rato, D., Syaiful, S. A., Riadi, M., \& Pabendon, M. B. (2019). Pengaruh umur panen tanaman primer dan jumlah tunas ratun sorgum manis terhadap produksi bioetanol. Penelitian Pertanian Tanaman Pangan, 3(3), 159-164. 